\title{
Insetos em presépios e as "formigas vestidas" de Jules Martin (1832-1906): uma curiosa manufatura paulistana do final do século XIX
}

\author{
Dante Martins Teixeira ${ }^{1}$ \\ Nelson Papavero \\ Miguel Angel Monné ${ }^{3}$
}

RESUMO: Encontrados no Brasil desde os primórdios da colonização portuguesa, os presépios logo tiveram de adaptar-se à realidade local, circunstância muito propícia ao aparecimento de concepções heterodoxas e ao emprego de elementos exóticos da fauna e flora de cada região. Como registros envolvendo insetos são muito pouco comuns, chama a atenção que fêmeas de saúva, Atta sp. (Hymenoptera, Formicidae), tenham sido aproveitadas na composição de presépios no estado de São Paulo. Tendo subsistido pelo menos até a década 1960, os "presépios de formigas" existentes em cidades como Embu das Artes poderiam estar relacionados às "formigas vestidas" criadas por Jules Martin, curiosa manufatura paulistana do último quartel do século XIX.

PALAVRAS-ChaVE: Atta. Hymenoptera. Formicidae. "Formigas vestidas". Jules Martin. Insetos. Presépio. Folclore paulista.

ABSTRACT: Present in Brazil since the beginning of Portuguese colonization, crèche nativity scenes were soon adapted to local reality, a propitious circumstance for the appearance of heterodox conceptions and the use of exotic elements of the fauna and flora peculiar to each region. As records about insects are very uncommon, it is noteworthy that females of leaf-cutting ants, Atta sp. (Hymenoptera, Formicidae), were used to compose crèche nativity scenes in São Paulo State. Having subsisted at least up to the decade of 1960, the "ant crèches" of cities such as Embu das Artes could be related to the then famous "dressed ants" created by Jules Martin, a curious manufacture of the city of São Paulo in the last quarter of the 19th century. KEYWORDS: Atta. Hymenoptera. Formicidae. "Dressed ants". Jules Martin. Insects. Crèche nativity scenes. Folklore of São Paulo.
1. Professor Adjunto do Departamento de Vertebrados, Museu Nacional-UFRJ, Rio de Janeiro (RJ). Bolsista do Conselho Nacional de Desenvolvimento Científico e Tecnológico (CNPq). E-mail: <dan te.teixeira@pq.cnpq.br>

2. Professor Assistente do Museu de Zoologia-USP, São Paulo (SP). Bolsista do Conselho Nacional de Desenvolvimento Científico e Tecnológico (CNPq). E-mail: <nel sonpapavero@gmail.com>

3. Professor Associado do Departamento de Entomologia, Museu Nacional-UFRJ, Rio de Janeiro (RJ). Bolsista do Conselho Nacional de Desenvolvimento Científico e Tecnológico (CNPq). E-mail: $<$ monne@uol.com.br> 
4. Ver L. da C. Cascudo (1954a) e A. Tarzia (1994).

5. Ver F. Cardim (1925).

6. Ver L. da C. Cascudo (1954a).

7. Ver J. de F. Figueiredo Filho (1962).

8. Ver L. Edmundo (1950).

9. Ver M. B. Cotrim (1962).
Introdução

Embora celebrações do nascimento de Cristo existam pelo menos desde o final do século III, reza a tradição que o presépio teria surgido apenas em 1223, quando São Francisco de Assis reuniu uma manjedoura, um boi e um burro nos bosques de Greccio para facilitar a compreensão do evento pelos habitantes locais. Com o passar dos anos, essas cenas de adoração do Menino Jesus tornar-se-iam cada vez mais complexas, congregando numerosos elementos além do arranjo mais conhecido da Sagrada Família cercada pelos Reis Magos, anjos, pastores e certos animais. Na Lisboa de 1391, as freiras do Salvador teriam montado o primeiro presépio português, costume que se transformaria, ao longo do século XVI, em uma espécie de auto religioso de grande apelo popular ${ }^{4}$.

A montagem de presépios parece ter chegado ao Brasil com os jesuítas, havendo notícias de um "devoto presépio" erigido na cidade de Salvador para o Natal de 1583, enquanto o colégio do Rio de Janeiro abrigaria um outro presépio "que fazia esquecer os de Portugal" em dezembro de 15845. Este último estaria ambientado em uma "lapa" feita pelo "irmão Barnabé Telo", disposição coerente com a crença de Jesus ter nascido em uma caverna dos arredores de Belém, tradição medieval bastante generalizada nos países ibéricos ${ }^{6}$. Quase desaparecidas nos dias de hoje, essas "lapinhas" foram - por séculos a fio - um elemento central nas comemorações natalinas do Brasil, podendo ocupar a "metade de um salão" com uma estrutura sofisticada a ponto de apresentar "cascatas em miniaturas derramando água de pequenos rochedos artificiais", relato alusivo a um presépio organizado na cidade de Januária (Minas Gerais) no ano de 1929. Segundo essa narrativa, na região de Bom Jesus da Lapa (Bahia) "cada habitação, por mais modesta, possuía a sua [lapinha] erguida na sala da frente, adornada de folhas verdes e de flores"7.

Além de incorporar influências culturais diversas, os presépios montados no Brasil tiveram de adaptar-se à realidade local, circunstância muito propícia ao aparecimento de concepções heterodoxas e ao emprego de elementos bem mais exóticos do que simples flores e folhas colhidas nas vizinhanças, havendo referências à inclusão de uma "fauna variada" pelo menos

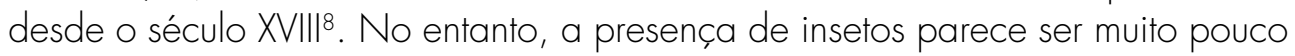
comum, peculiaridade que torna digno de nota um curiosíssimo arranjo encontrado há poucas décadas em Embu das Artes (São Paulo). Armado no convento das Irmãs Educadoras-Enfermeiras, prédio anexo à antiga igrejinha de Nossa Senhora do Rosário - templo fundado pelos jesuítas em 1690 - esse presépio permanece quase desconhecido, tendo escapando da obscuridade graças a uma reportagem de Marcelo Barbosa Cotrim publicada no segundo caderno da "Folha de São Paulo" de 1 de fevereiro de 1962", artigo ilustrado por uma reveladora fotografia (Figura 1). 


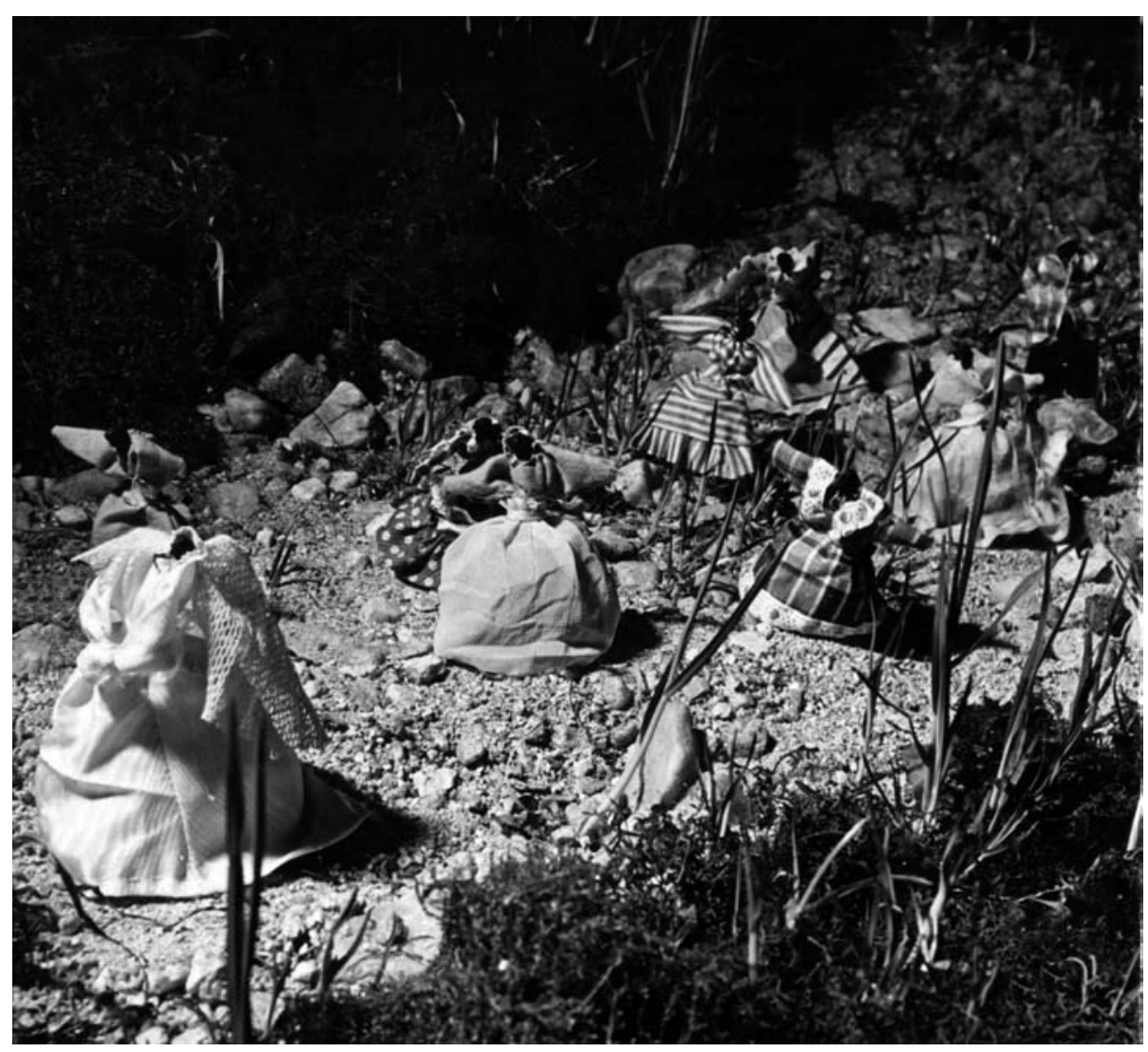

Figura 1 - $\bigcirc$ "presépio de formigas" armado no convento das Irmãs Educadoras-Enfermeiras em Embu das Artes, São Paulo, no ano de 1962. Banco de Dados, Folha de São Paulo, São Paulo.

Conforme o testemunho prestado pelas freiras, a tradição do presépio de Embu remontaria aos jesuítas, os quais teriam decidido excluir os Reis Magos do conjunto por não acreditarem que uma comitiva vinda do Oriente pudesse ter chegado a tempo de presenciar o nascimento de Jesus em Belém. Sempre coube aos religiosos providenciar as imagens da Sagrada Família, anjos e querubins, enquanto "os índios" - e posteriormente os devotos em geral - encarregavam-se da construção de cenário composto sobretudo por árvores e arbustos, paisagem predominante mesmo nos idos de 1962. Na noite de Natal, os moradores do bairro mantinham vivo o costume ancestral de visitar o presépio para pedir a bênção do Menino Deus levando oferendas de verduras, frutas e ovos.

A montagem desse presépio tinha início nos meses de outubro e novembro, quando as crianças das redondezas saíam à cata das tanajuras ou içás - fêmeas aladas de Atta sp. (Hymenoptera, Formicidae) - que nessa época emergiam dos formigueiros para sua revoada nupcial (Figura 2). Após terem "arrancados" os "ferrões" e as "pernas", as formigas eram vestidas "com roupinhas masculinas ou femininas" e levadas para "ornamentar a trilha" existente no presépio, representando 


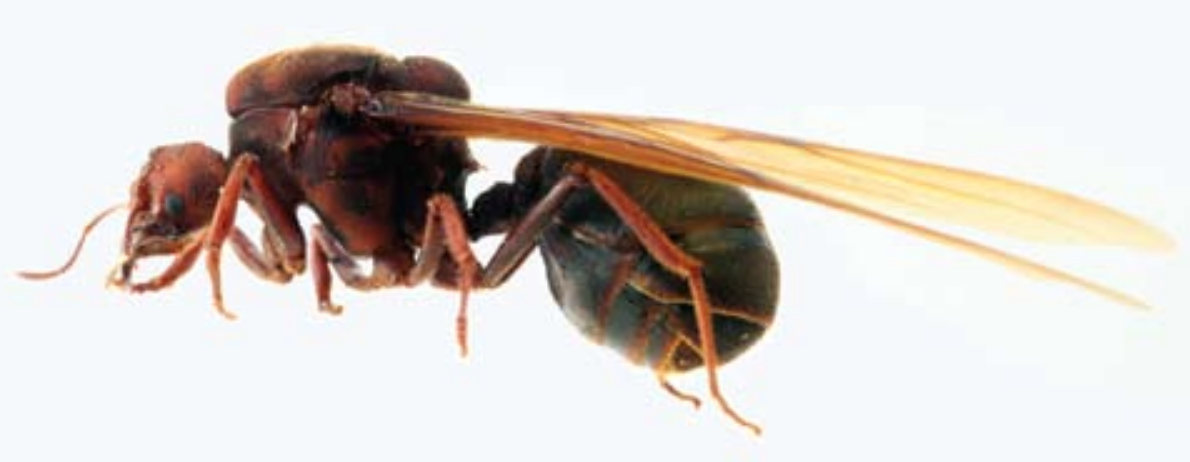

Figura 2 - Vista lateral de uma fêmea alada de Atta sexdens (Hymenoptera, Formicidae), pertencente ao Departamento de Entomologia, Museu Nacional-UFRJ. Fotografia Dr. José Ricardo Miras Mermudes (Departamento de Zoologia-UERJ).

assim o devoto "cortejo dos moradores do bairro"10. Malgrado as tanajuras possam assumir certo aspecto antropomórfico ao perderem a cabeça (i.e. os "ferrões") e algumas pernas, as oito "formigas vestidas" presentes na foto assemelham-se a pequenos espantalhos compostos apenas em parte por restos de insetos. Não obstante, a "cabeça" desses bonequinhos parece realmente estar formada pelo tórax de uma içá, havendo pelo menos um exemplar no qual é possível distinguir uma pata remanescente (Figura 3). Como o tórax das fêmeas aladas de Atta sexdens Linnaeus, 1758 - uma das saúvas mais comuns em São Paulo - oscila de 7,2 mm a $8,5 \mathrm{~mm}$ de comprimento $(\mathrm{n}=31$, média $8,16 \mathrm{~mm})$, parece razoável concluir que as pretensas "formigas vestidas" retratadas devessem alcançar entre 55 e $65 \mathrm{~mm}$ de altura, tamanho muito superior aos 20,6 mm - 24,5 mm de comprimento total das fêmeas aladas dessa mesma espécie $(n=21$, média $21,43 \mathrm{~mm})$. $O$ resultado final indica um trabalho apurado, pois os trajes femininos desses pequenos manequins exibem numerosos detalhes como xales e diminutos toucados.

A manufatura de Jules Martin

Em São Paulo, o estranho costume de "vestir formigas" assumiria uma feição mundana absolutamente distinta do caso anterior, tornando-se uma próspera manufatura entre o final do século XIX e o começo do século XX. As 

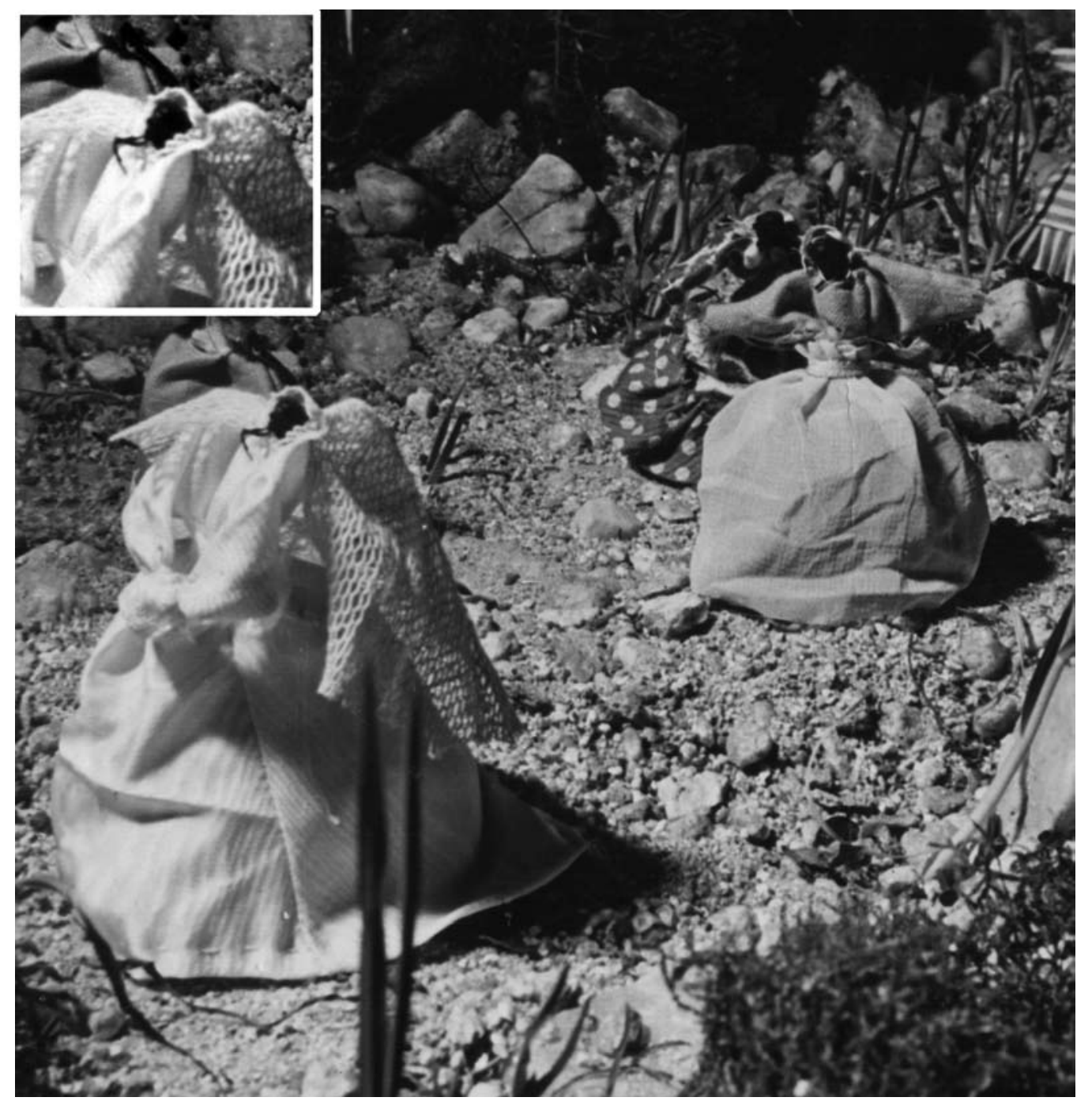

Figura 3 - As "formigas vestidas" do presépio de Embu das Artes, São Paulo. A julgar pela pata remanescente mostrada no detalhe, a "cabeça" desses bonequinhos estaria formada apenas pelo tórax de uma formiga adulta. Banco de Dados, Folha de São Paulo, São Paulo.

melhores referências sobre o assunto encontram-se na "Excursão pelos dominios da Entomologia", raro opúsculo de João Alfredo de Freitas publicado no Recife em 1886. Em seu terceiro capítulo, essa obra destaca que as tanajuras então representavam "uma fonte de renda para muitos industriosos", os quais se ocupavam "em vesti-las em costumes da moda" ou caricaturavam "algum personagem conhecido", vendendo-as "como curiosidade" por "boas somas" capazes de atingir em torno de "trinta e duas patacas"ll. Este seria o preço de um "casal de tanajuras" comercializado pela Casa Jules Martin, estabelecimento pertencente ao famoso pintor, arquiteto e litógrafo francês radicado em São Paulo entre 1868 e 1906, personagem mais conhecido nos dias de hoje por ter

Annals of Museu Paulista. v. 16. n.2. July - Dec. 2008. 
12. Nascido em Marselha, França, em 22 de fevereiro de 1832, Jules Martin mostrou-se notável por seu espírito empreendedor, tendo desenvolvido várias atividades distintas ao longo de sua vida no Brasil. Em 1869, instalaria a primeira oficina litográfica da cidade de São Paulo, denominando-a "Imperial Litografia" após receber a visita, em 1875, do imperador Dom Pedro II. Localizado na rua Boa Vista, esse estabelecimento seria posteriormente transferido para o antigo número $61 \mathrm{da}$ rua de São Bento, sendo esse o endereço associado às "formigas vestidas" que comercializava. Típico representante de uma época com forte presença francesa, Jules Martin faleceu em São Paulo no dia 18 de setembro de 1906. Para maiores detalhes, ver E. V. da Costa (2000), P. C. de Moura (1932) e M. L. F. de Oliveira (2003).

13. Ver J. A. de Freitas (1886).

14. Ver O. B. de Camargo (1996).

15. O marcado apetite dos antigos paulistanos por formigas torradas foi registrado por diversos autores como E. da S. Bruno (1953); L. da C. Cascudo (1954b); A. d' E. Taunay (1926-1929) e A de Saint-Hilaire (1936). Nascido em 1837, o General Couto de Magalhães confessa que, na São Paulo de sua infância, a tanajura era "vendida em tabuleiros pelas ruas", sendo iguaria apreciada tanto pelas camadas mais pobres quanto "pelas melhores famílias". "Mais tarde", porém, essas últimas "só a comiam às escondidas" ... "e isso depois que o poeta estudante Júlio Amando de Castro, em pleno teatro de gala, pois era um 7 de setembro, bateu palmas e, no meio de pasmo geral, seguido de gargalhadas dos estudantes, daí re- idealizado o Viaduto do Chá ${ }^{2}$. Os insetos seriam vendidos dentro de uma caixinha com uma inscrição na tampa: "Formigas Tanajuras Vestidas. Unico deposito. S. Paulo, Brazil. Casa Jules Martin"13.

Na temporada lírica, Jules Martin "vestia as formigas de acordo com as [peças] em cartaz: índios enfeitados de penas multicolores, bailarinas de vaporoso tutu etc." 14. Tal relação parece ter sido marcada o suficiente para inspirar o ferino comentário de que o artífice francês guardava "grande mágoa" dos "caipiras" e "pretas africanas" encarregados de apregoar "saúvas torradas" como gulodice pelas ruas ${ }^{15}$, pois preferia ver essas formigas "escravizadas" conforme "os figurinos de sua imaginação delicada" 16 . Não causa surpresa, portanto, que Jules Martin imprimisse uma estampa satírica na qual a demolição do palacete dos Barões de Tatuí - fortes opositores à abertura do Viaduto - era levada a cabo por um industrioso enxame de tanajuras (Figura 4). Dedicada ao mesmo tópico, uma segunda gravura do autor reproduz o sugestivo desenho de uma tanajura vestida de bailarina entre suas várias alegorias (Figura 5) ${ }^{17}$.

Ao descrever um par de içás trajadas "á phantasia", o livro de Alfredo de Freitas atribui ao elemento masculino um enfeitado "redingote de velludo azulferrete", um longo "manto branco", "botinas de cano alto de setim verde claro" e um "chapeu de pluma escarlate ao lado". Não menos elegante, sua companheira cobria-se com um decotado vestido de "longa cauda bem justo ao corpo" feito

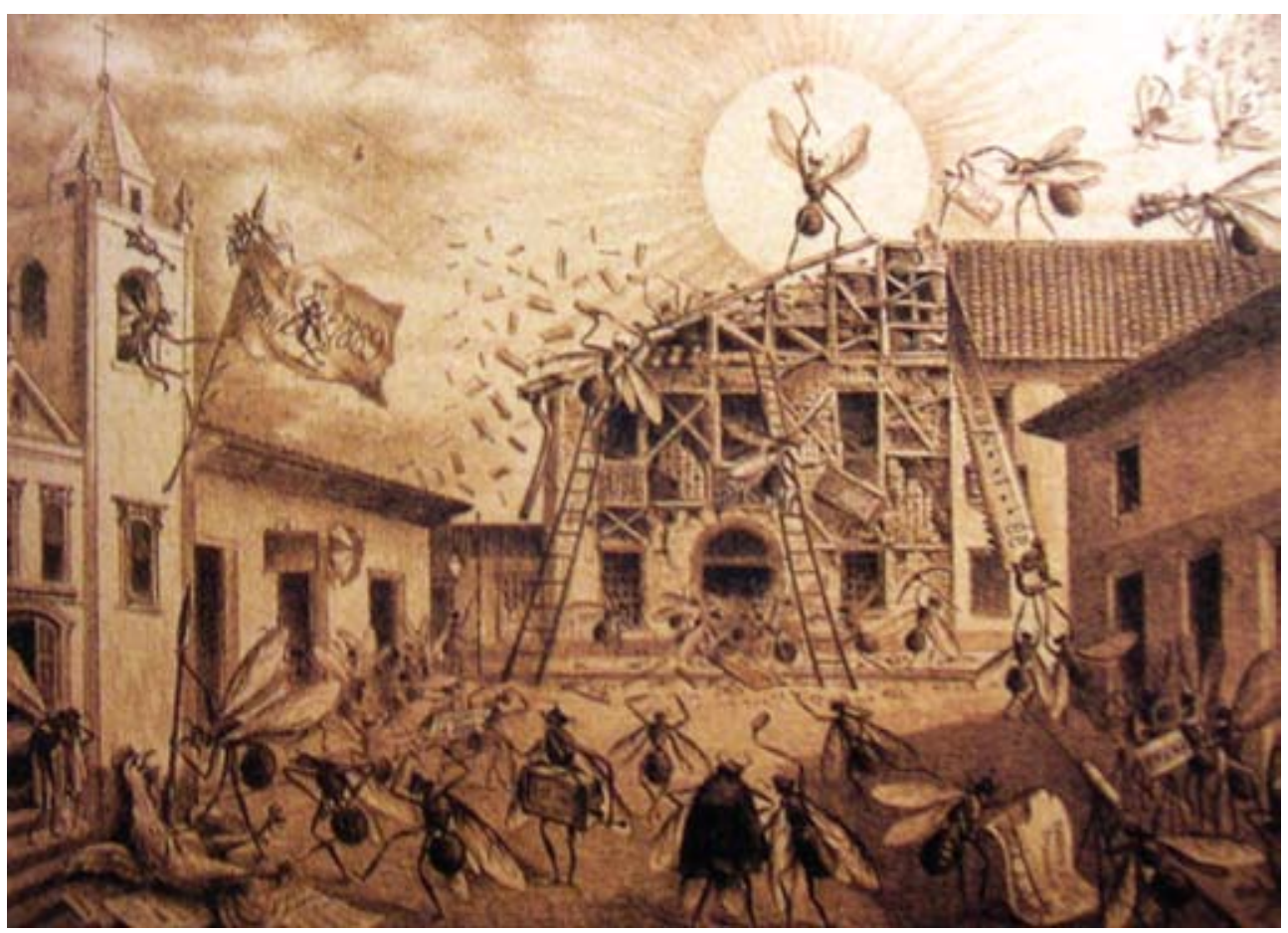

Figura 4 - Gravura satírica de Jules Martin mostrando a demolição do palacete dos Barões de Tatuí por tanajuras. Cortesia do Dr. Benedito Lima de Toledo (FAU-USP). 


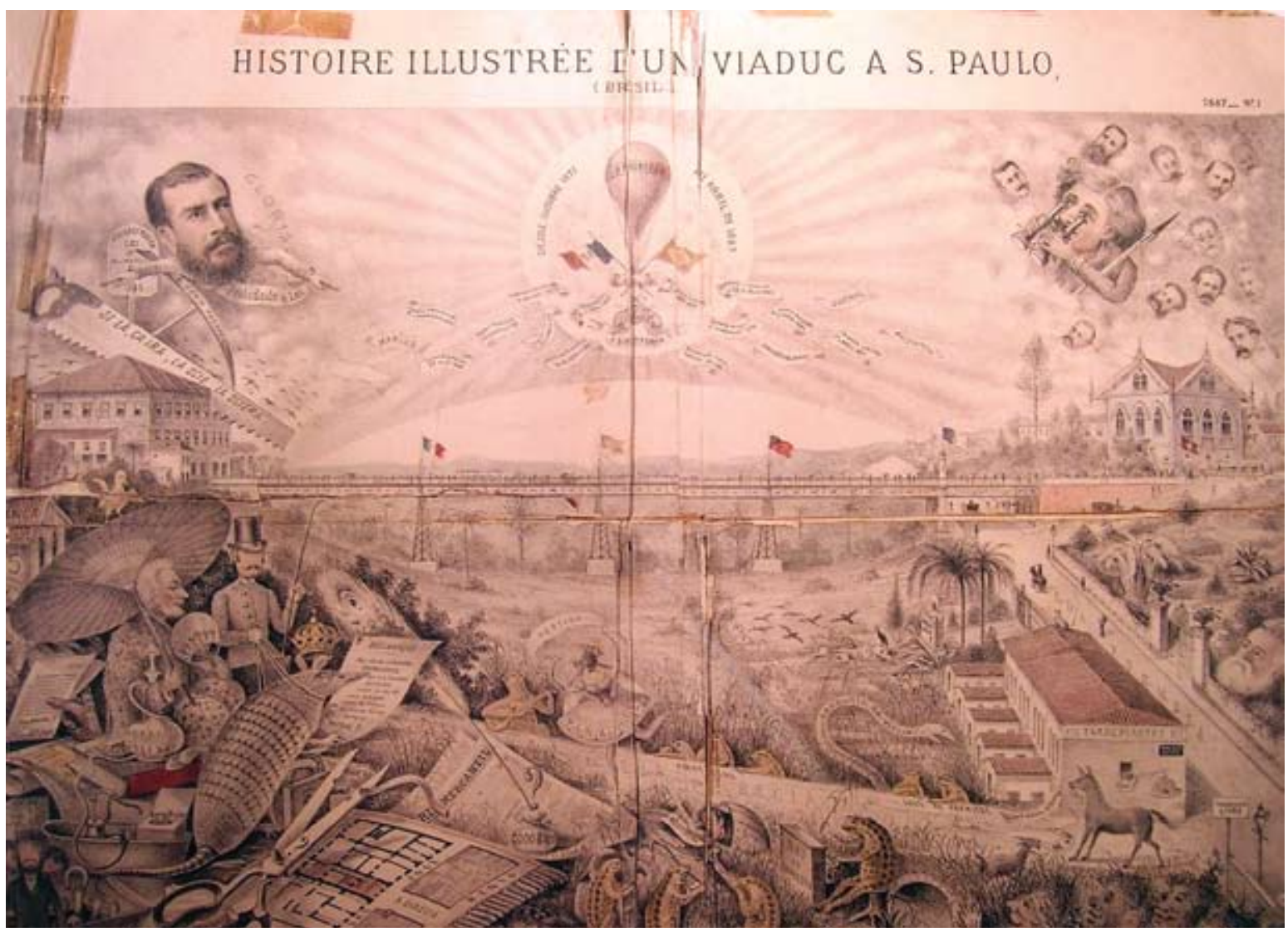

Figura 5 - Gravura satírica de Jules Martin sobre a abertura do Viaduto do Chá, composição que inclui a sugestiva imagem de uma tanajura travestida de bailarina. Cortesia do Dr. Benedito Lima de Toledo (FAU-USP).

de "setim côr de rosa com frisos de ouro" cujas mangas, "abertas de alto á baixo", permitiam "descortinar os negros braços esguios" do inseto. "Sob essa rica tunica via-se uma linda sáia de setim branco, bordada á capricho com ouro em fio", enquanto a cabeça carregava "um laço dourado em vez de chapeu" e os pés, "quasi cobertos pelos vestidos, estavam agazalhados n'umas botinas de salto a Luiz XV, com fivella e bico fino, do ultimo gosto". "Em fim, ambas ostentavam muito luxo e chiquismo"18.

Outras fontes sugerem que as "formigas vestidas" de Jules Martin se tornaram um artigo popular o suficiente para permitir o aparecimento de imitadores ${ }^{19}$. Em sua comédia em três atos intitulada "Caiu o Ministério!", peça datada de 1882, um dos personagens criados pelo jornalista Joaquim José da França Júnior, conhecido autor do teatro brasileiro, trata as "formigas vestidas" como um "souvenir" exótico marcadamente relacionado a São Paulo. Na quarta cena do terceiro ato, ao criticar o provincianismo dos que the faziam corte, a formosa Beatriz classifica semelhante falta de imaginação como proverbial o suficiente para tornar muito fácil reconhecer a origem de seus pretendentes graças aos mimos oferecidos. "Os do Ceará mandam corrupiões, os do Pará redes, sultando formidável rôlo, começou a recitar um soneto que principiava assim: 'Comendo içá, comendo cambuquira/ Vive a afamada gente paulistana/ $\mathrm{E}$ aquelas a que chamam caipira/ Que parecem não ser da raça humana ...' Não pode concluir, que lh'o não consentiu o berreiro de indignação que se levantou do coração à guelra dos patriotas. $\mathrm{O}$ poeta, porém, salvou o pelo e a pele, pois os estudantes que haviam preparado a troça (que eram, aliás, paulistas) tiveram a previdência de acautelar-lhe a retirada e o esconderijo". Ver C. de Magalhães (1946).

16. "Na rua de 'Sete Casinhas', onde hoje é a rua do Thesouro, e no Beco das Mi- 
nas, actualmente 11 de Agosto, caipiras e pretas africanas, com insistencias interesseiras, apregoavam verduras, frutas, gulodices e saúvas torradas, e isso com grande magua de Jules Martin, que preferia escravisá-las e vesti-las pelos figurinos de sua imaginação delicada." Ver A. de C. Mendes (1927).

17. Ver B. L. de Toledo (1996).

18. Ver J. A. de Freitas (1886).

19. Ver O. B. de Camargo (1996).

20. Ver J. J. da França Júnior (1980).

21. In A. Forel (1895).

22. Ver [Anônimo] (1888).

23. Compare K. Lenko \& N. Papavero (1979) com K. Lenko \& N. Papavero (1996). paus de guaraná e macacos de cheiro, os de Pernambuco cajus secos e abacaxis, os de São Paulo formigas vestidas e figos em calda" 20 .

Conforme assinala o naturalista Emílio Goeldi, uma breve nota sobre essas "formigas vestidas" seria publicada na revista parisiense "La Nature" durante o último quartel do século XIX21. Baseado no relato de um certo Senhor Labarre, antigo residente no Brasil, o articulista anônimo esclarece que, na província de São Paulo, as grandes formigas chamadas de "formigas tanajuras" eram preparadas, certa época do ano, por mulheres que as "tostavam como castanhas" e saíam pelas ruas anunciando esse "surpreendente alimento" aos gritos de "va iça" ("Vai içá?"). Vestidas como "pequenas bonecas para atrair a curiosidades dos passantes", as "femeas de saúbas" também eram vendidas nas "lojas de modistas" como artigo "bastante procurado pelos estrangeiros", sendo acondicionadas em caixinhas de papelão munidas da etiqueta "Formigas tanajuras vestidas. Unico disposito em San-Paulo (Brazil)", dizeres indicativos da "Casa Jules Martin"22. Calcada em "rascunhos do Senhor Labarre", a ilustração fornecida mostra formigas providas de cabeça, antenas e patas, portanto algo bastante distinto daquilo observado no "presépio de formigas" montado em Embu das Artes (Figura 6).

Apesar de significativas, as referências disponíveis apresentam várias lacunas e contradições, além de oferecer poucos detalhes quanto aos insetos propriamente ditos. Como nenhuma informação adicional veio à luz em quase duas décadas ${ }^{23}$, a recente descoberta de um par dessas "formigas vestidas" constituiu uma agradável surpresa, haja vista a aparente inexistência de material

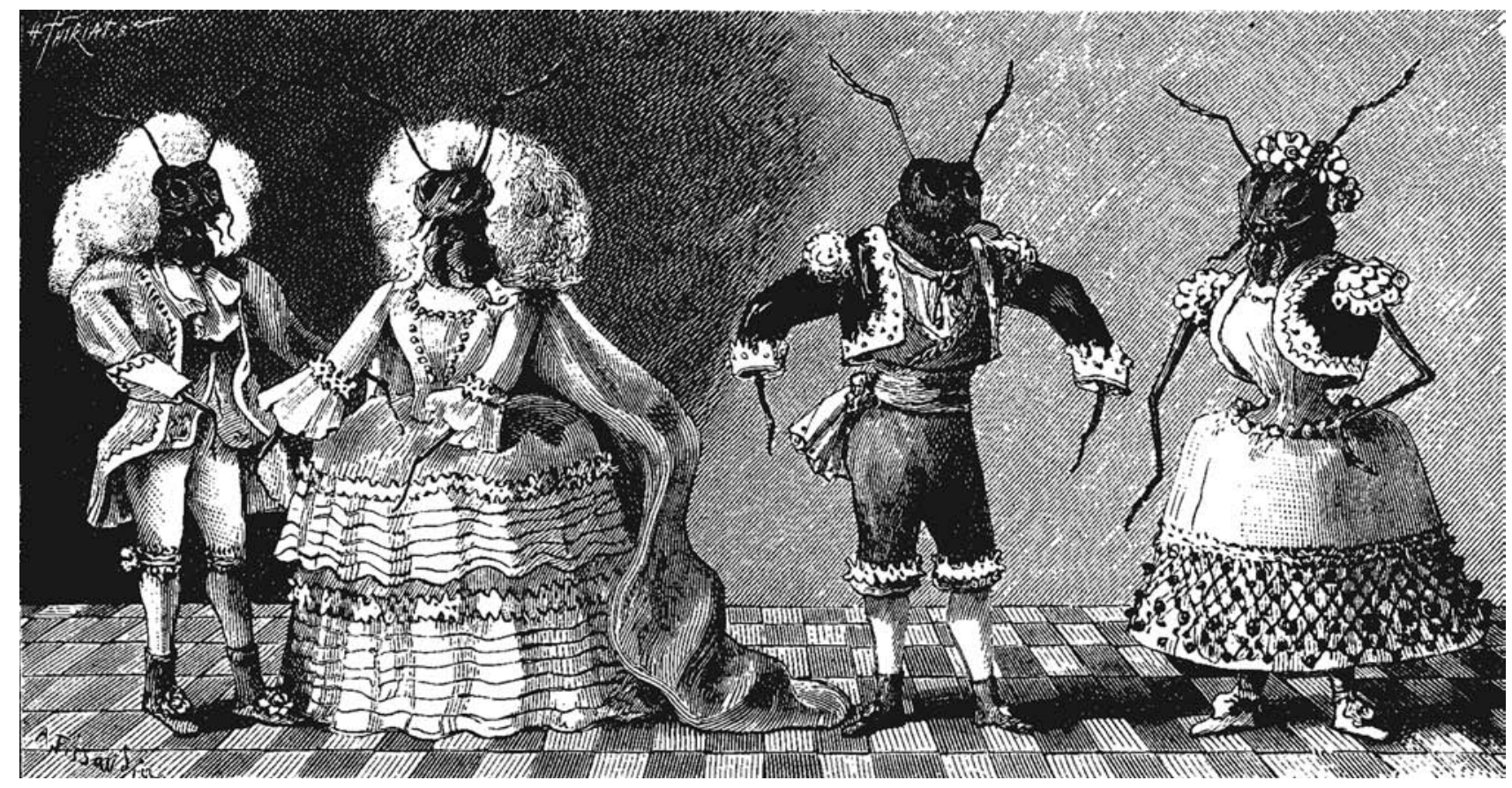

Figura 6 - As "formigas vestidas" de Jules Martin segundo ilustração publicada na revista parisiense "La Nature", 1888. 
em coleções. Na verdade, sequer o Museu Paulista logrou manter exemplares em seu acervo, malgrado o antigo livro de registro contenha, na folha 57 da seção relacionada às "Curiosidades e Artefactos brasileiros e estrangeiros", o registro de cinco "saúvas vestidas, industria paulistana", todas provavelmente oriundas da Coleção Sertório (Figura 7)24.

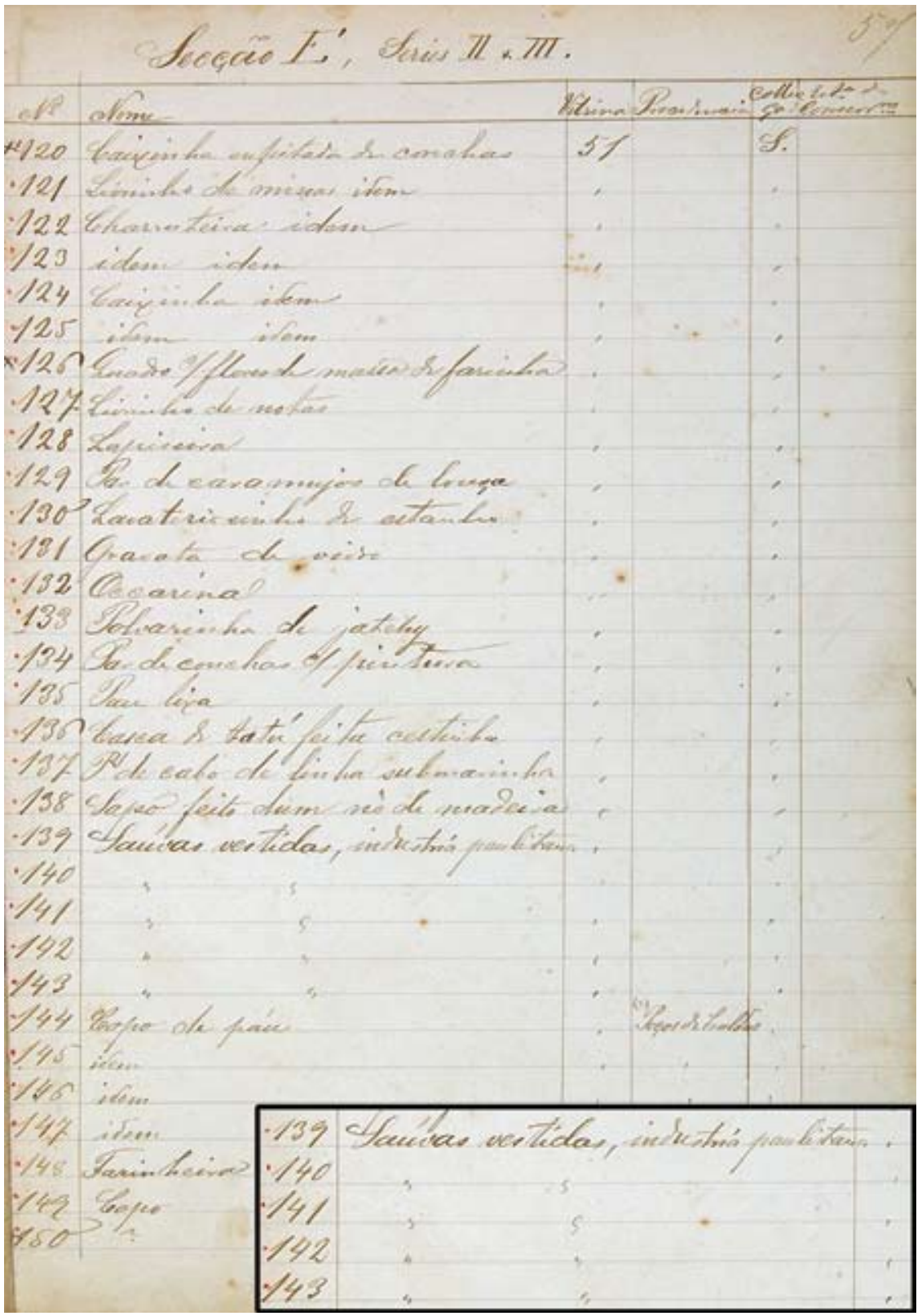

Figura 7 - Reprodução da folha 57 do antigo livro de registro do Museu Paulista. $\bigcirc$ detalhe mostra o tombamento de cinco "saúvas vestidas, industria paulistana". Cortesia da Dra. Heloisa Barbuy (Museu Paulista-USP).
24. Esse estudo não teria sido concluído sem os comentários e a inestimável colaboração da Dra. Heloisa Barbuy (Museu Paulista, Universidade de São Paulo), que chamou nossa atenção para importantes referências bibliográficas e várias ilustrações de Jules Martin, além de gentilmente reunir os dados sobre as "formigas vestidas" tombadas no antigo livro de registro do $\mathrm{Mu}-$ seu Paulista. 
As "formigas vestidas"

Típico exemplo do comércio de Jules Martin, as "formigas vestidas" aqui descritas foram adquiridas, em torno de 1880, por Ibrahim Carneiro da Cruz Machado, formando da Faculdade de Direito do Largo de São Francisco, São Paulo, como um presente exótico para a noiva e futura esposa do comprador, permanecendo na família por várias décadas (Figura 8). Concordando com a sucinta narrativa fornecida por Alfredo de Freitas em mais de um aspecto, essas

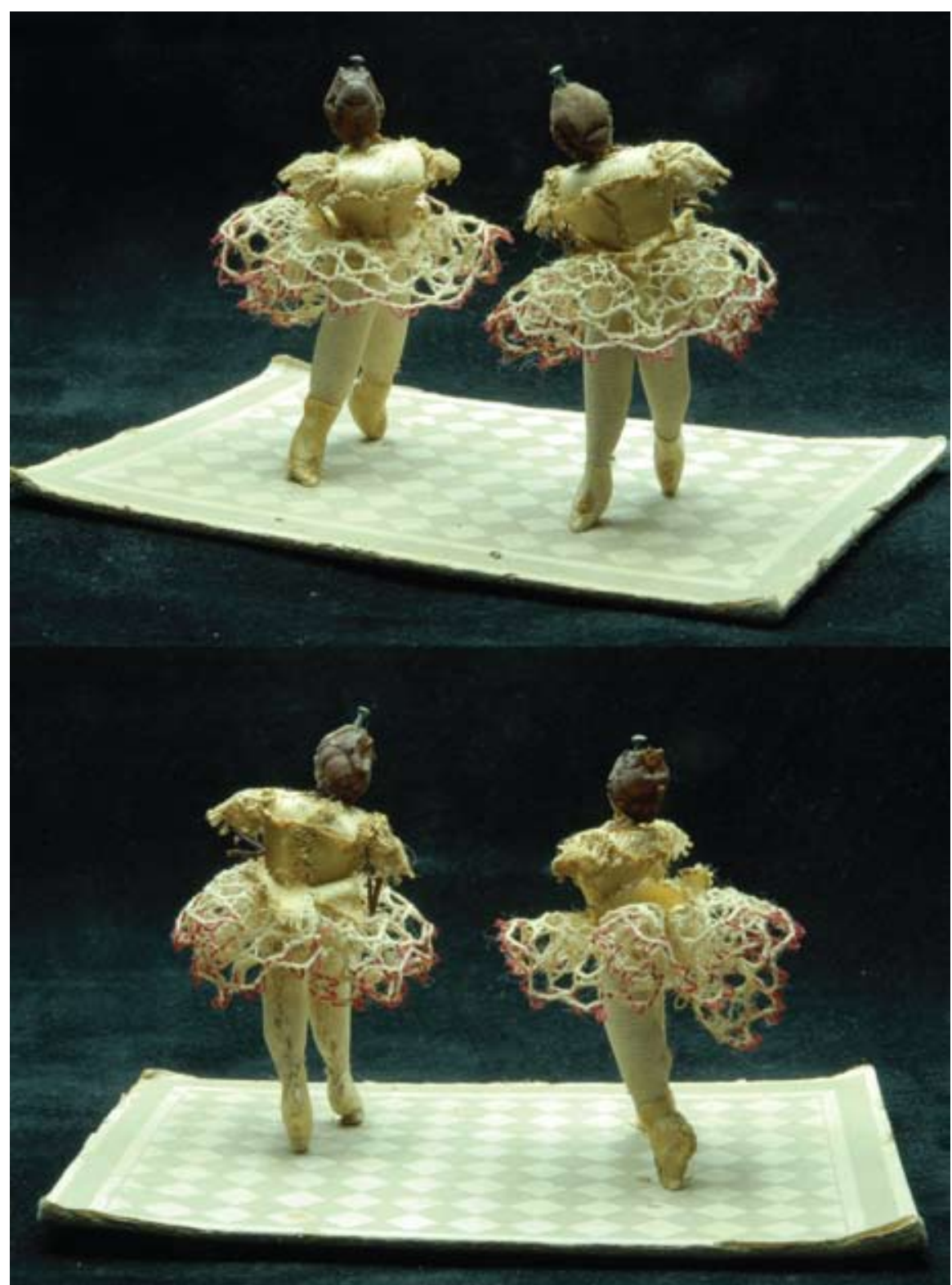

Figura 8 - Aspecto geral de duas "formigas vestidas" caracterizadas como bailarinas. Manufatura Jules Martin, São Paulo. Fotografia Dr. João Alves de Oliveira (Museu Nacional-UFRJ). 
tanajuras estão acondicionadas em uma caixinha de papelão grosso com 1,4 $\mathrm{mm}$ de espessura revestido externamente por um fino papel verde musgo. Possuindo 104 mm de comprimento por $69 \mathrm{~mm}$ de largura e $65 \mathrm{~mm}$ de altura, tal embalagem atinge $67 \mathrm{~mm}$ de altura quando fechada, diferença conferida pela tampa de 105 $\mathrm{mm}$ de comprimento por $70 \mathrm{~mm}$ de largura e $18 \mathrm{~mm}$ de altura. Na face superior dessa última, observa-se uma etiqueta de papel verde claro com os seguintes dizeres impressos em branco: "Formigas tanajuras vestidas. Unico deposito em S. Paulo (Brazil). Casa Jules Martin. R. de S. Bento 61" (Figura 9) ${ }^{25}$.

Com $97 \mathrm{~mm}$ de comprimento por $65 \mathrm{~mm}$ de largura, um quadrilátero do mesmo papelão grosso serve como base de fixação para as "formigas vestidas", acomodando-se à justa no interior da caixa. Colado na face superior desse suporte, um fino papel estampado em branco e cinza cobre toda superfície disponível, emulando o desenho de um piso ladrilhado. $\bigcirc$ verso não possui qualquer acabamento, mas apresenta uma etiqueta de papel azul claro com $42 \mathrm{~mm}$ de comprimento e $28 \mathrm{~mm}$ de largura na qual se encontra a inscrição "Unico depositario n'esta provincia. Jules Martin. Rua de S. Bento 37. S. Paulo". Impressa em tinta preta, essa sentença mostra o "37" corrigido à mão para "61" (Figura 10).
25. Cabe destacar o auxílio prestado pelo Dr. João Alves de Oliveira (Museu Nacional, Universidade Federal do Rio de Janeiro), autor do impecável registro fotográfico das "formigas vestidas" descritas nesse ensaio, bem como a generosa colaboração do Dr. José Ricardo Miras Mermudes (Departamento de Zoologia-UERJ), que forneceu as fotografias de $\mathrm{Hy}$ pocephalus armatus e Atta sexdens

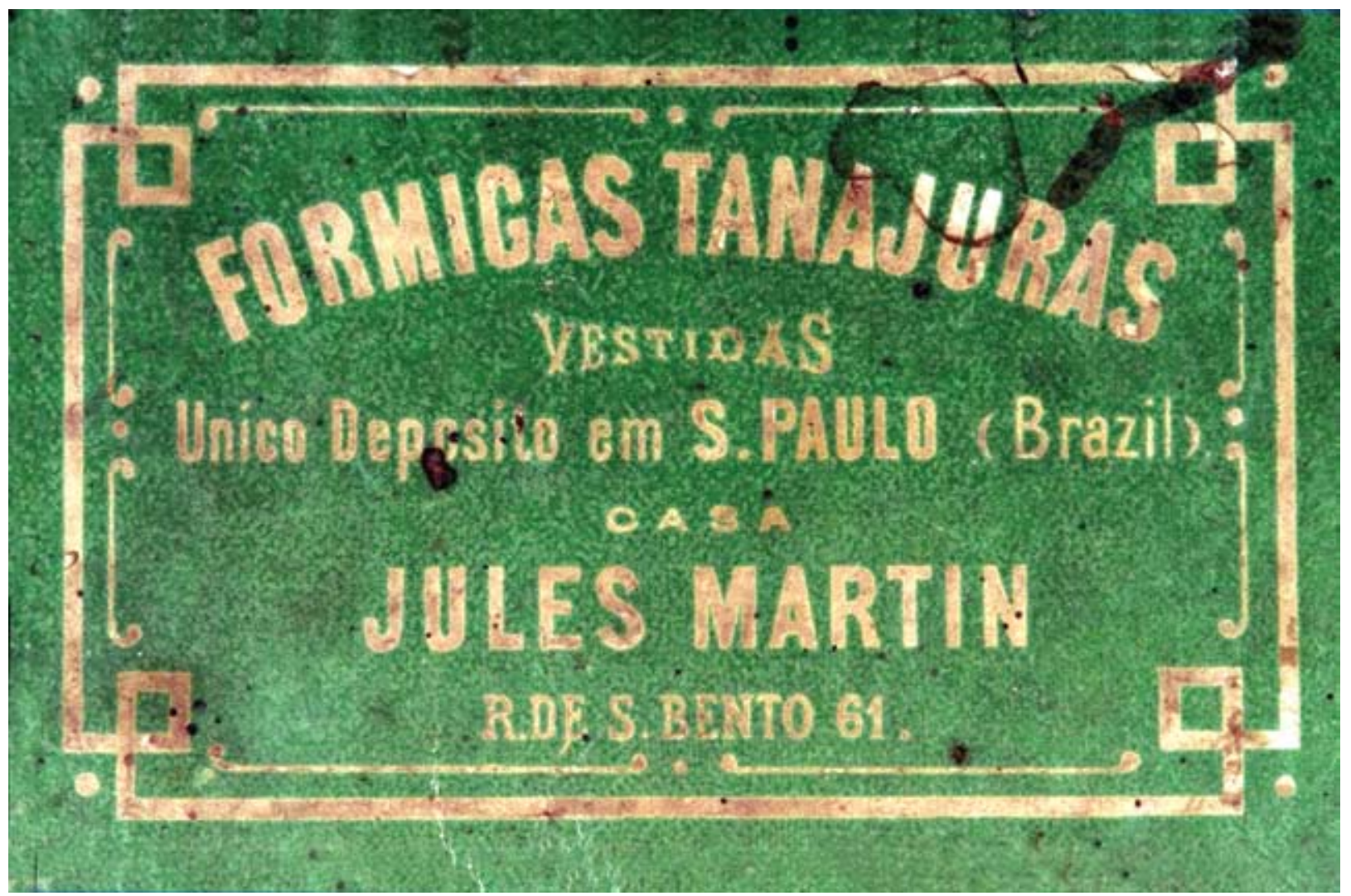

Figura 9 - Tampa da caixa utilizada por Jules Martin com os dizeres: "Formigas tanajuras vestidas. Unico deposito em S. Paulo (Brazil). Casa Jules Martin. R. de S. Bento 61". Fotografia Dr. João Alves de Oliveira (Museu Nacional-UfRJ). 


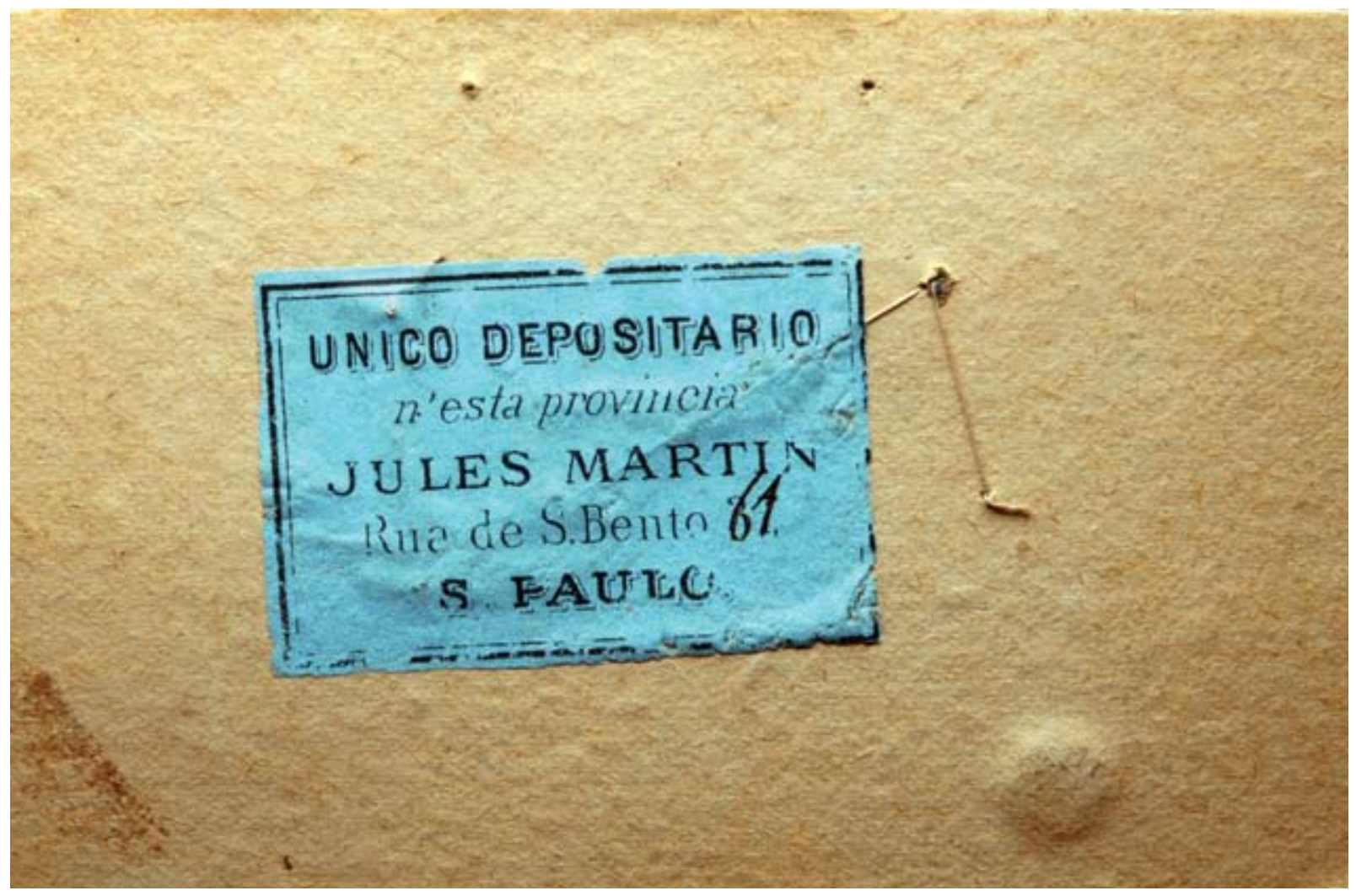

Figura 10 - Etiqueta utilizada por Jules Martin com os dizeres: "Unico depositario n'esta provincia. Jules Martin. Rua de S. Bento 37. S. Paulo", estando o "37" corrigido à mão para "61". Fotografia Dr. João Alves de Oliveira (Museu NacionalUFRI).

26. Compare com B. Hölldobler \& E. O. Wilson (1990).
Fixadas por intermédio de longos fios atados na face inferior da base de papelão, as duas "formigas vestidas" presentes personificam singelas bailarinas em passos de dança. Com $50 \mathrm{~mm}$ de altura, ambas ostentam um corpete branco com curtas e bufantes mangas de renda, o proverbial saiote com cerca de $35 \mathrm{~mm}$ de diâmetro tecido em renda branca com um fio vermelho na borda, longas meias brancas e sapatilhas da mesma cor providas de um pequeno arremate amarelo à guisa de fecho. Ao invés de "formigas vestidas" na acepção da palavra, essas figuras femininas não passam de pequenos bonecos de pano no quais foram fixadas determinadas partes do corpo de uma tanajura (Figura 11 ).

Apenas a "cabeça" e os "braços" das "formigas vestidas" de Jules Martin de fato correspondem a fragmentos de um inseto. Tendo em conta $\circ$ tamanho e diâmetro apresentados, os "braços" seriam formados pelo fêmur, tíbia e tarso do segundo ou terceiro par de patas de uma fêmea alada de saúva, ao passo que a "cabeça" não passa do tórax com as $\operatorname{coxas}^{26}$. Os "braços" parecem ter sido colados em seu devido lugar, enquanto a "cabeça" está presa ao corpinho do boneco graças a um alfinete de metal com o pronoto voltado para cima ou para baixo conforme o caso (Figura 12). Tais despojos, entretanto, não permitem 


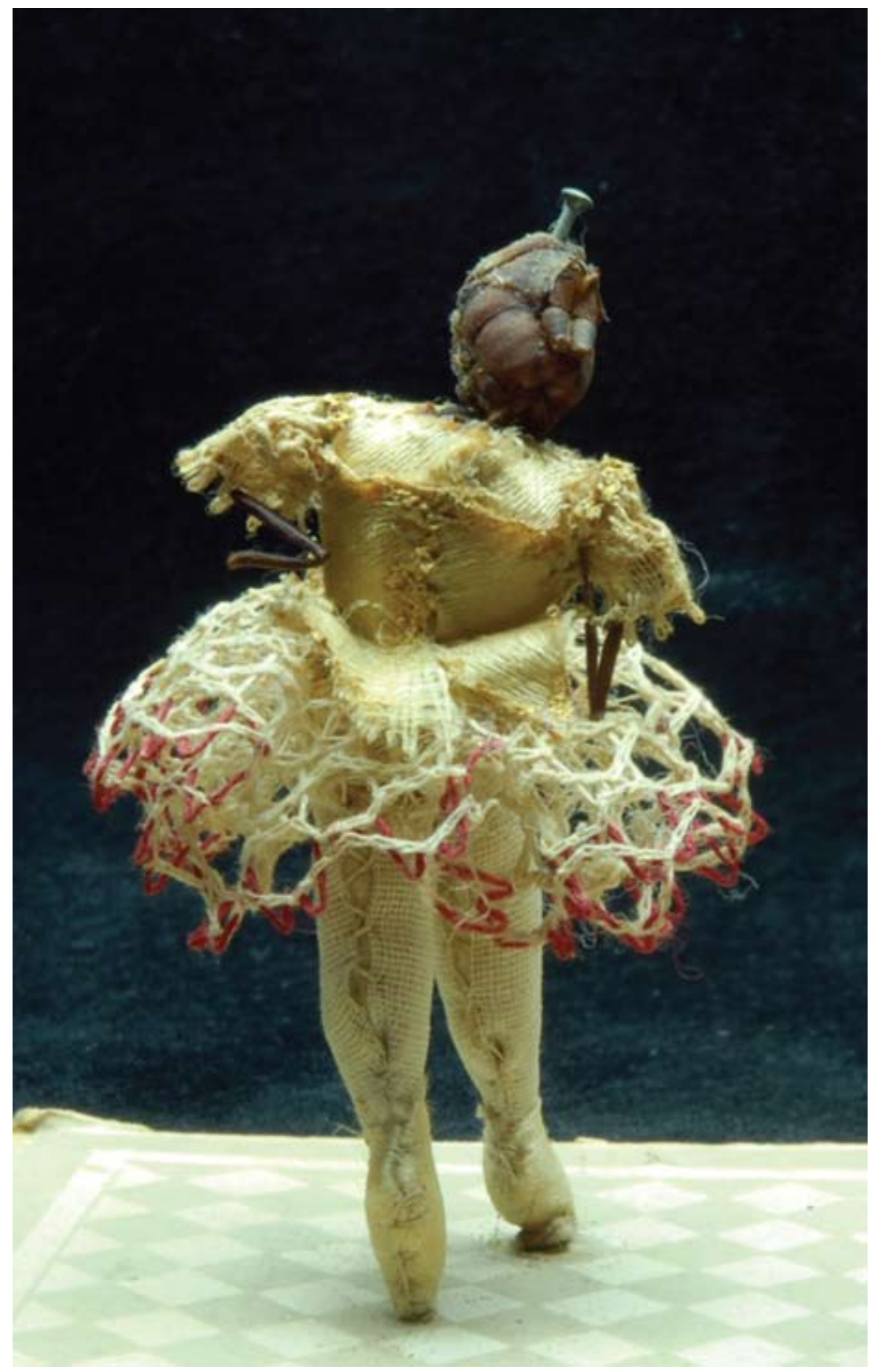

Figura 11 - Vista ventral de uma das "formigas vestidas" comercializadas por Jules Martin. Fotografia Dr. João Alves de Oliveira (Museu Nacional-UFRJ). 

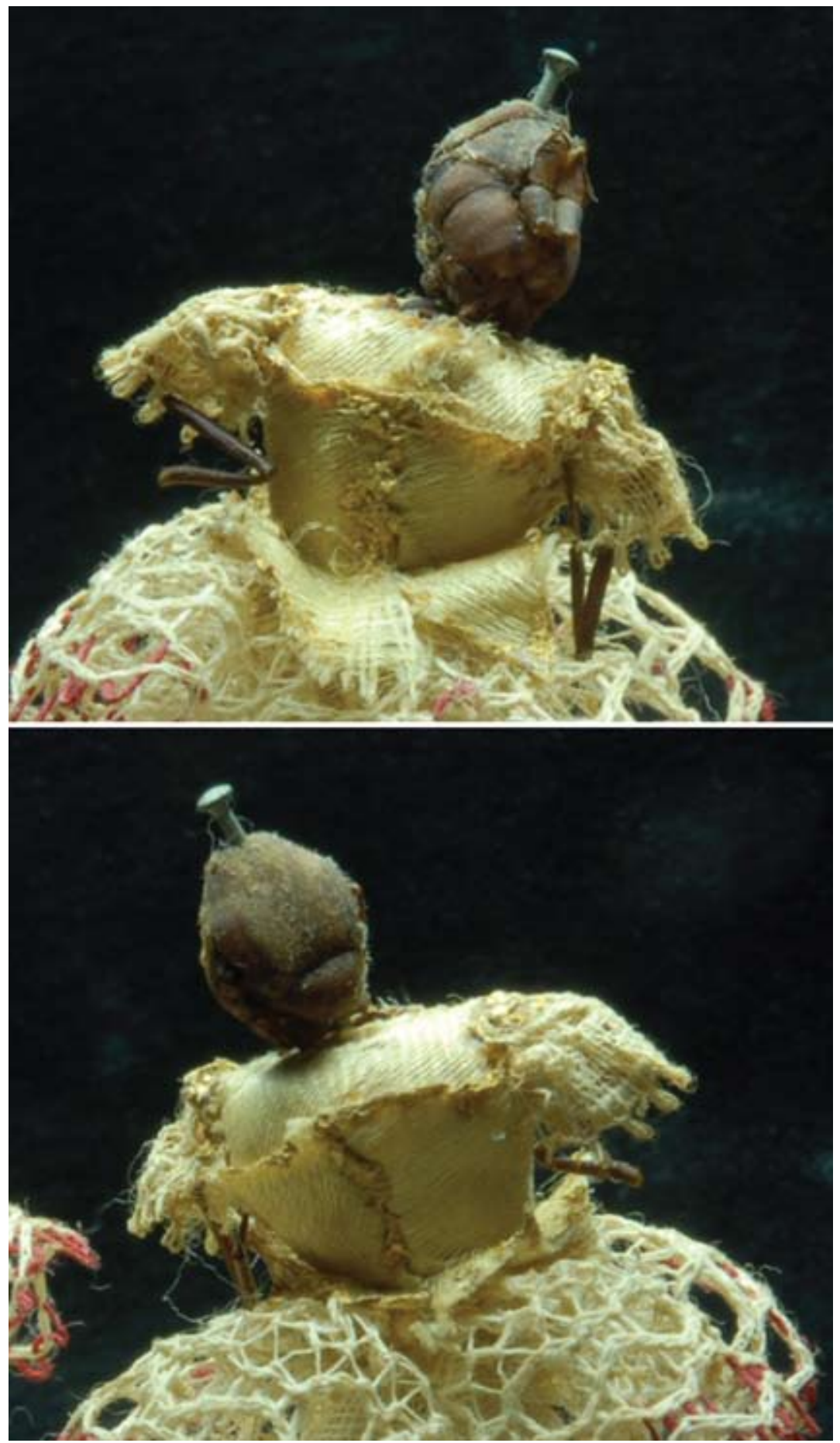

Figura 12 - Vista dorsal e ventral da "cabeça" e "braços" das "formigas vestidas" de Jules Martin, únicas partes realmente compostas por fragmentos de uma tanajura. Fotografia Dr. João Alves de Oliveira (Museu Nacional-UFRJ). 
a identificação da tanajura utilizada, pois a diagnose dos representantes do gênero Atta baseia-se na morfologia das operárias ou na genitália dos machos e existem pelo menos dez espécies conhecidas para o Brasi|27. Das quatro saúvas registradas para São Paulo, Atta sexdens destaca-se como a mais comum em numerosos municípios do oeste, centro e nordeste do estado ${ }^{28}$.

Semelhante disposição comprova o descarte prévio da verdadeira cabeça do animal e reforça a idéia de que as irregularidades do tórax e os remanescentes dos apêndices teriam sido aproveitados como um simulacro de rosto provido de vagas feições humanas. A julgar pela tanajura ilustrada em uma das gravuras de Jules Martin (Figura 13), a base livre do alfinete de metal serviria
27. Ver B. Bolton (1995); T. Borgmeier (1959); T. M. C. Della Lucia (1993) e C. R. Gonçalves (1942).

28. Ver F. A. M. Mariconi (1970).

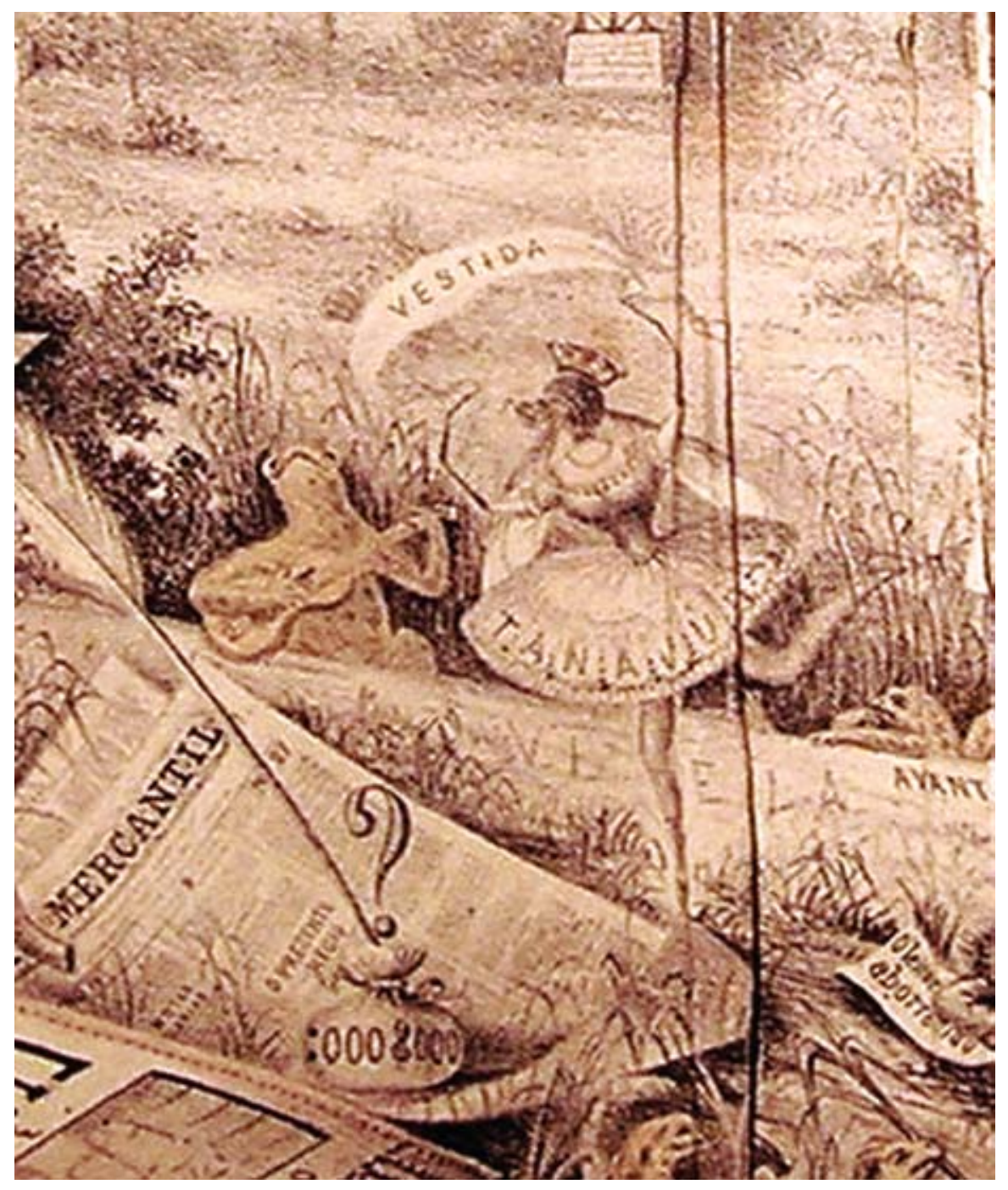

Figura 13 - Detalhe da tanajura travestida de bailarina presente na gravura satírica sobre a abertura do Viaduto do Chá impressa por Jules Martin. Cortesia do Dr. Benedito Lima de Toledo (Faculdade de Arquitetura e Urbanismo-USP). 
29. Chamado de "vaqueiro", "carocha", "lapinha" ou "iaiá de cintura", Hypocephalus armatus é um besouro capaz de atingir até $67 \mathrm{~mm}$ de comprimento que apresenta discreto colorido negro, antenas curtas e aspecto bem diverso daquele observado em grande parte dos demais representantes da família Cerambycidae. Após sua descoberta na primeira metade do século XIX, esse coleóptero converteu-se em um autêntico mistério durante décadas, permanecendo conhecido apenas do exemplar-tipo durante vários anos. Tal raridade despertaria a cobiça dos colecionadores, os quais chegaram anunciar seu interesse nesse inseto através de folhetos ilustrados e oferecer entre 10 e 20 libras esterlinas por um único exemplar, quantia nada desprezível nos idos de 1884. Só em meados do século XX foi possível estabelecer que a espécie em questão possui hábitos fossoriais e emerge quando chove o suficiente, podendo ser encontrada caminhando pelo solo dos "campos gerais" no norte de Minas Gerais e partes adjacentes da Bahia. Para maiores detalhes ver R. L. Araújo (1954); E. Goeldi (1894); K. Lenko \& N. Papavero (1996) e M. A. Vulcano, F. S. Pereira \& M. T. de Mendonça (1980).

30. Ver R. L. Araújo (1954).

31. Ver M. A. Vulcano, F. S. Pereira \& M. T. de Mendonça (1980).

32. Ver B. Lehane (1969). como apoio para um tipo qualquer de coifa ao invés de fixar a cabeça do inseto, minúcia que torna o desenho publicado na revista "La Nature" muito pouco verossímil.

\section{Discussão}

Apesar de também ser oriundo do Brasil, o segundo caso registrado de insetos em presépios não guarda qualquer relação com o arranjo de formigas descrito para São Paulo, configurando-se como uma manifestação cultural muito diversa e bem menos elaborada que envolve Hypocephalus armatus Desmarest, 1832 (Coleoptera, Cerambycidae), um curioso besouro encontrado apenas nos "campos gerais" do norte de Minas Gerais e partes adjacentes da Bahia ${ }^{29}$. Segundo as observações do insigne entomólogo Renato Lion de Araújo, esse inseto era bem conhecido pela população de várias localidades do extremo norte de Minas Gerais, sendo capturado "por mulheres e crianças" durante a busca de "pedras, musgos e outros objetos com que enfeitam suas lapinhas". Amarrados com uma fita colorida na acentuada constrição existente entre o protórax e os élitros (Figura 14), os exemplares obtidos eram suspensos vivos no teto das grutas, onde permaneciam "inermes por muitos dias, agitando inutilmente as pernas até que a exaustão pusesse termo ao suplício" 30 . De acordo com o testemunho pessoal de nosso saudoso amigo, os moradores da região usavam os Hypocephalus armatus "como anjinhos", enquanto outras fontes acrescentam que tais coleópteros serviam de diversão para as crianças, sendo pendurados sobre os berços como estranhos brinquedos ${ }^{31}$.

Tampouco o costume de "vestir insetos" revela-se muito comum, sendo digno de nota o caso das famosas "pulgas vestidas" (Siphonaptera) provenientes do México. Segundo consta, essa manufatura remontaria ao século XVIII, tendo sido concebida como um exótico "souvenir" por freiras interessadas em angariar fundos para a lgreja. A expensas de grande habilidade manual e de "olhos devastados" pelo trabalho minucioso ${ }^{32}$, as religiosas conseguiam produzir uma notável variedade de figuras que representavam desde camponeses, botequineiros, diaristas e vendedores de frutas até "damas da noite" e policiais. Tampouco faltavam arranjos mais complexos, inclusive uma cena da Paixão mostrando um Jesus crucificado tendo a seus pés Maria Madalena, Barrabás, soldados romanos e outros personagens bíblicos.

Tal como nas formigas de Jules Martin, essas "pulgas vestidas" não passavam de diminutos manequins de pano, massa ou fibras vegetais coloridas nos quais um inseto colado servia de cabeça, havendo exemplares providos de chapéus, adereços diversos e mesmo longas madeixas confeccionadas com fios 


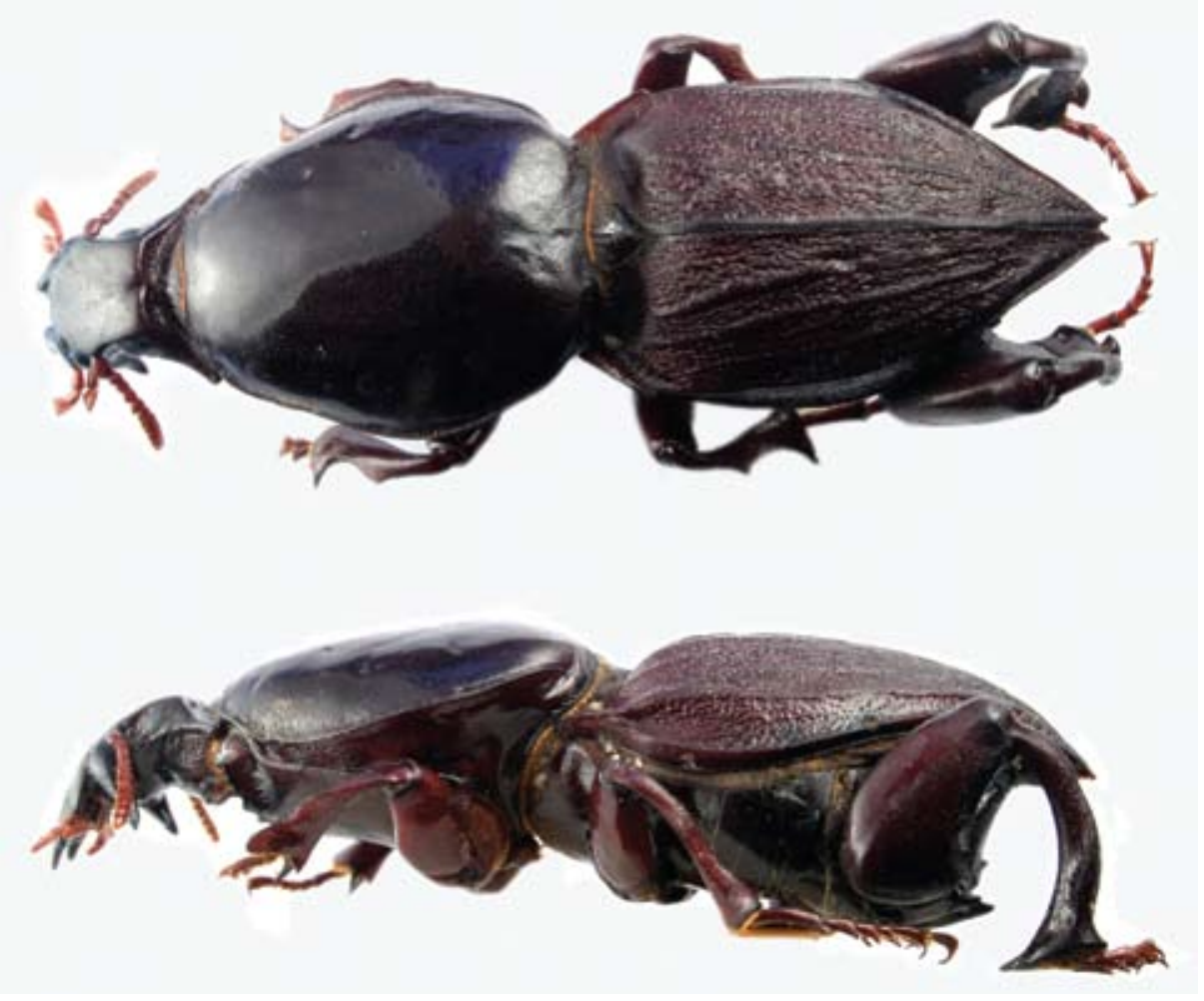

Figura 14 - Vista dorsal e lateral de um macho de "vaqueiro", Hypocephalus armatus (Coleoptera, Cerambycidae), pertencente ao Departamento de Entomologia, Museu NacionalUFRJ. Fotografia Dr. José Ricardo Miras Mermudes (Departamento de Zoologia-UERJ).

de cabelo humano. Acompanhados ou não por lentes de aumento, esses bonequinhos eram montados em caixinhas de papelão ou em cascas de nozes, avelãs ou pistaches devidamente ornamentadas com as mais variadas pinturas, formando minúsculos dioramas (Figura 15). Tendo alcançado grande notoriedade no rastro dos célebres "circos de pulgas" do século XIX ${ }^{33}$, as "pulgas vestidas" logo começariam a ser manufaturadas por leigos, reforçando a forte vertente miniaturista do artesanato mexicano. Por motivos não muito claros, essa tradição declinaria ao longo do século XX, tendo quase desaparecido já na década de 1990.

Estranhas aos nossos olhos, as "formigas vestidas" em absoluto destoam do grande número de "excentricidades zoológicas" em voga no século XIX, elenco composto por itens tão díspares como "circos de pulgas", "bestas sapientes" e uma longa relação de "monstros", "seres prodigiosos" ou animais bizarros capazes de atrair grande público nas principais praças da Europa e América do $\mathrm{Norte}^{34}$. Não surpreende, portanto, que a preparação de quimeras ${ }^{35}$ - animais sem existência real formados por partes de várias espécies distintas - e
33. Ver BALLANTINE (1958) e BERTOLOTTO (1834). Vale lembrar ainda que, no ano de 1879 , o compositor russo Modest Petrovich Mussorgsky lançaria sua famosa "Canção da Pulga" ("Песня о блохе"), obra baseada no quinto ato do "Fausto" de Johann Wolfgang von Goethe. Tendo alcançado enorme sucesso desde então, essa música reproduz uma das cenas passadas na taverna de Auerbach, quanto Mefistófeles canta a loucura de um rei levado à ruína por amar uma pulga a ponto de vesti-la com trajes suntuosos e nomeá-la para seu círculo de ministros.

34. Ver R. Jay (2003).

35. Relacionadas aos troféus cinegéticos tão apreciados na Europa, essas quimeras voltariam à baila nos últimos anos, dando origem à chamada "taxidermia rogue" e ao polêmico trabalho de alguns artistas contemporâneos como Jeannie M. e Maurizio Catalan. Vide K. G. Blüchel (1999) e D. Ottinger (2003). 


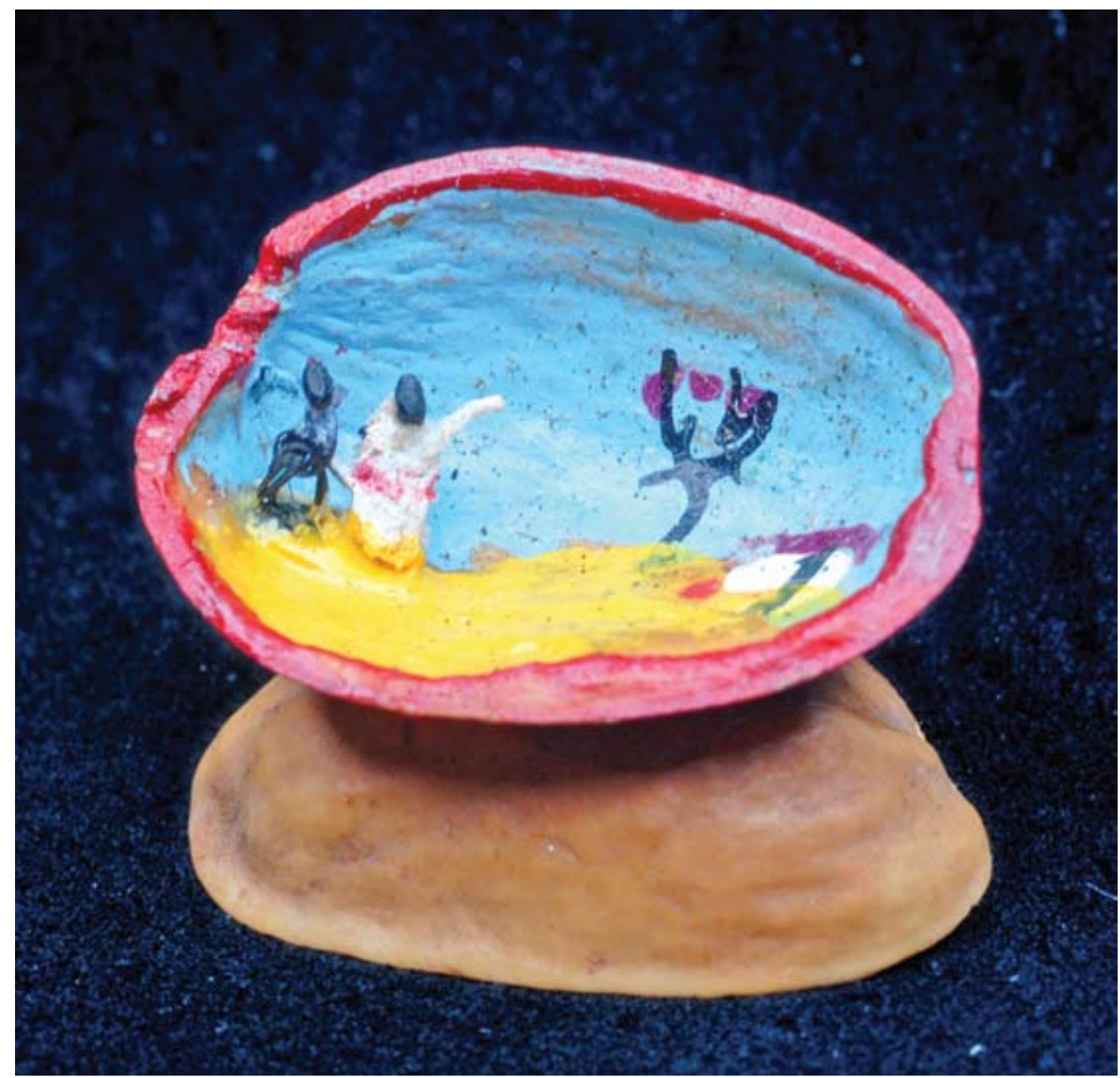

Figura 15 - Arranjo de duas "pulgas vestidas" em uma casca de pistache. Fotografia Dr. João Alves de Oliveira (Museu Nacional-UFRJ).

36. As preparações do alemão Hermann Ploucquet alcançariam sucesso inaudito durante o evento, conquistando seguidores na Inglaterra e conferindo grande impulso à "taxidermia antropomórfica" no restante da Europa. Considerada macabra e de gosto duvidoso nos dias de hoje, essa técnica sobreviveria por longos anos, tendo sido praticada comercialmente no Brasil pelo menos até a década de 1970 . Para maiores detalhes, ver S. T. Asma (2001); M. Browne a chamada "taxidermia antropomórfica" - animais montados em posturas humanas - também florescessem nesse período, adquirindo maior destaque a partir da Grande Exposição organizada em Londres no ano de $1851^{36}$. Embora favorecidas - e talvez influenciadas - pelo espírito da época, as "formigas vestidas" de Jules Martin não podem ser facilmente associadas com qualquer um dos casos anteriores, pois o emprego do animal como simulacro do homem constitui recurso muito presente na trajetória do Ocidente cristão, correspondendo a um espectro demasiado amplo de manifestações culturais que abarcavam desde as soberbas iluminuras dos manuscritos medievais ${ }^{37}$ até a peculiar indústria renascentista das "jenny hanivers" 38 . Apesar de não se mostrarem tão freqüentes quanto os macacos - sem dúvida alguma o modelo por excelência ${ }^{39}$ - os insetos 
também conquistariam certo espaço em iniciativas desse tipo, fato bem exemplificado pelas "Papilloneries humaines" do artista francês Charles-Germain de Saint-Aubin (1748), uma série de gravuras nas quais borboletas duelam, vão ao teatro ou se ocupam de atividades cotidianas (Figura 16$)^{40}$.

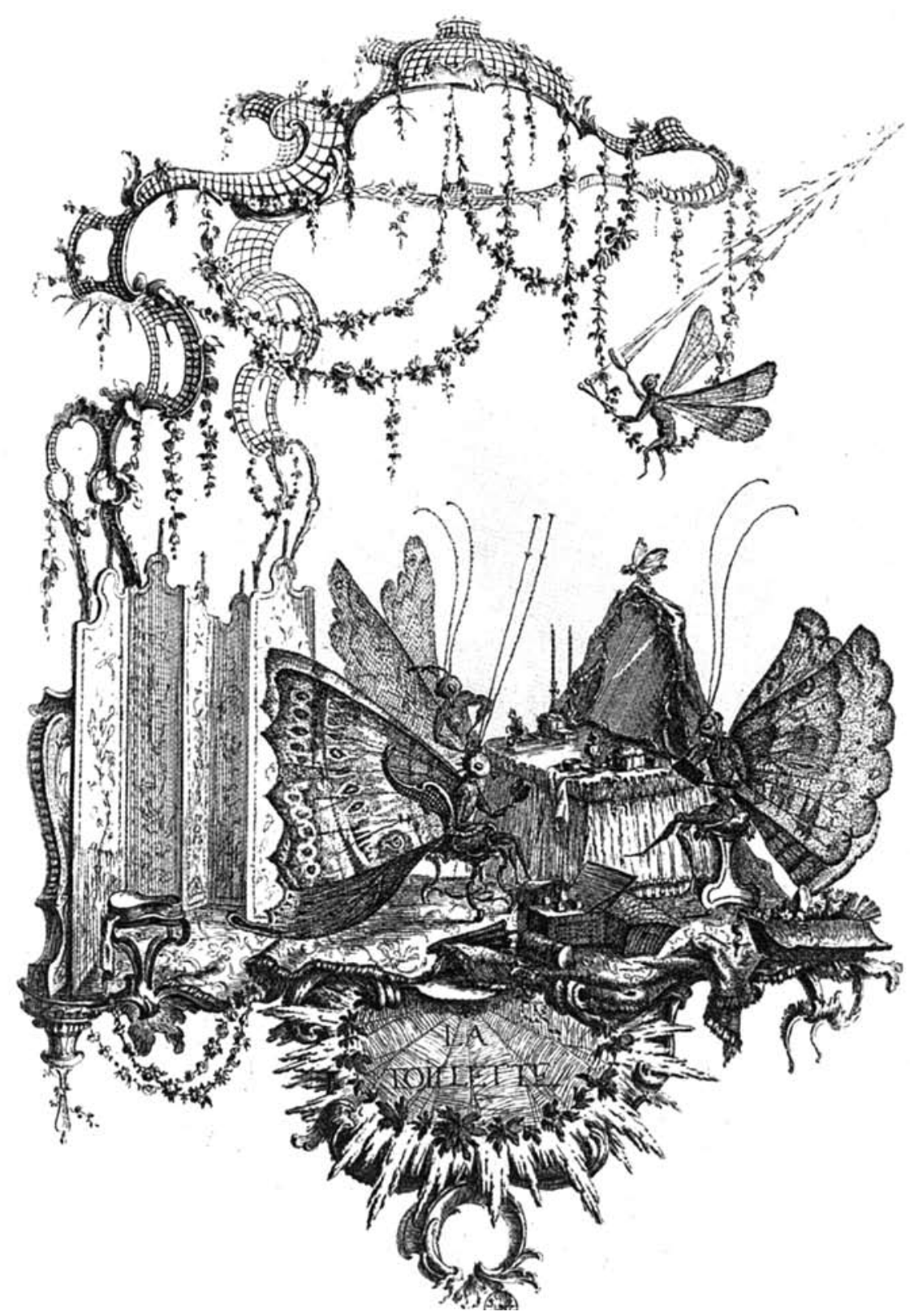

Figura 16 - "La Toillette", uma das gravuras do artista francês Charles-Germain de Saint-Aubin pertencente à série "Papilloneries humaines" (1748). (ca. 1890); R. J. Chinnery (2001); C. Frost (1987); M. Henning (2007) e H. Ploucquet (1861).

37. Para maiores informações, consulte-se D. Hassig (1999); C. Hicks (1993); F. Klingender (1971); B. Resl (2007); J. E. Salisbury (1994) e M. H. Tesnière (2005).

38. De origem incerta, essa denominação peculiar diz respeito a determinadas quimeras fabricadas em várias cidades da Itália, França e Países Baixos durante o século XVI. Embora pudessem imitar basiliscos, dragões e outros seres imaginários, as "jenny hanivers" muitas vezes possuíam evidente aspecto antropomórfico, sendo vendidas para os "gabinetes de curiosidades" como sereias ou "homens marinhos". Para atingir semelhante resultado, os artífices de tais monstrengos recortavam raias e outros peixes ou montavam engenhosas composições com os despojos de diferentes animais aquáticos e terrestres, não desprezado sequer restos humanos. A produção continuaria por pelo menos quatrocentos anos, pois exibições bem sucedidas dessas "sereias" teriam ocorrido mesmo no século XIX. Para maiores informações, vide R. Ellis (1996); W. Ley (1941); P. H. Smith \& P. Findlen (2002) e G. P. Whitley (1928).

39. Ver S. Zuckerman (1998).

40. Ver I. Néto (1996). 
41. Ver K. Lenko \& N. Papavero (1996).

42. Bem exemplificados por L. Büchner (1881) e M. Maeterlinck (1937).

43. Ver H. M. Ransome (1937).

44. Conforme Lindolpho Rocha Guimarães in K. Lenko \& N. Papavero (1996).

45. Agradecemos o inestimável testemunho concedido por D. ${ }^{a}$ Ecila do Amaral Campos, cabendo igualmente destacar as informações adicionais e os valiosos comentários sobre o texto efetuados pelo Dr. Eudes Campos, arquiteto e pesquisador do Arquivo Histórico Municipal Washington Luís, São Paulo.
A coincidência de detalhes sugere uma estreita relação entre 0 presépio de Embu das Artes e a manufatura de "formigas vestidas" ativa em São Paulo no final do século XIX. Considerando o caráter empreendedor e os múltiplos negócios desenvolvidos por Jules Martin no Brasil, não parece impossivel supor que $\mathrm{o}$ arquiteto francês transformasse uma tradição popular em oportunidade comercial, promovendo os ajustes necessários para alcançar sucesso nada desprezível. Na verdade, o hábito de travestir tanajuras em grotescas figurinhas de presépio teria sido, nos tempos de outrora, muito mais comum, pois existem notícias do mesmo costume em Taubaté no começo do século XX"11.

De certa forma, os "presépios de formigas" recordam as freqüentes analogias estabelecidas entre esses insetos e a nossa sociedade, fenômeno muito explícito na tradição literária européia e em incontáveis obras populares de História Natural dos séculos XIX e XX ${ }^{42}$. Com efeito, as formigas talvez sejam os artrópodes capazes de melhor cumprir o papel de espelho da humanidade, chegando a superar as próprias abelhas nesse mister ${ }^{43}$. Não chega a ser inusitado, portanto, que as crianças do interior do estado de São Paulo mantivessem o hábito de vestir as tanajuras pelo menos até o segundo quartel do século passado, confeccionando pequenas saias de papel de seda e fixando tais adereços nos volumosos abdomens das içás com o auxílio de uma cola preparada com polvilho ou farinha de trigo dissolvida em água ${ }^{44}$. Na passagem do século XIX para o XX, algo semelhante ocorria nas fazendas de café da região de Brotas, onde um dos passatempos exclusivos das meninas era promover o "casamento" das tanajuras, as quais ganhavam trajes de noiva. Após receber os atavios próprios da ocasião, inclusive grinaldas de filó, as pobres "nubentes" eram postas em liberdade para consumar seu "matrimônio" 45 , prática ao extremo curiosa caso se leve em conta que - dentro de uma perspectiva totalmente antropocêntrica - as fêmeas aladas das saúvas emergem dos formigueiros buscando "se casar" ou - na saborosa linguagem de velhos lavradores do Paraná - "quando querem se perder", opinião reveladora de um conhecimento apreciável sobre a biologia desses insetos.

Embora atribuída aos jesuítas pela tradição oral, a origem dos "presépios de formigas" afigura-se bastante incerta e pode estar relacionada a motivos tão prosaicos como meros jogos infantis que, ao reconhecer a natureza feminina das tanajuras, terminavam conferindo-thes saias ou roupagens adequadas para as suas núpcias, tratando-as como autênticas bonecas vivas. A julgar pelas entrevistas efetuadas com os moradores de Embu das Artes, a possibilidade de esclarecer semelhante incógnita parece remota pois, a exemplo de várias outras manifestações de nossa antiga cultura popular, esse costume nada teria deixado além de lembranças muito vagas. 


\section{REFERÊNCIAS}

ANÔNIMO. Les fourmis comestibles au Brésil. La Nature: Revue des Sciences et de leurs applications aux Arts et a l'Industrie, Paris, 1er sem., p. 221-222, 1888.

ARAÚJO, R. L. Revisão da bibliografia e notas à ecologia de Hypocephalus armatus Desm., 1832 (Coleoptera, Hypocephalidae). Revista Brasileira de Entomologia, São Paulo, n. 2, p. 175-192, 1954.

ASMA, S. T. Stuffed animals and pickled beads: the culture and evolution of Natural History museums. Oxford: Oxford University Press, 2001.

BALLANTINE, W. Wild tigers and tame fleas. New York: Rinehart, 1958.

BERTOLOTTO, L. The history of the flea with notes and observations. London: Crozier, 1834.

BLÜCHEL, K.G. (Org.). Die Jagd. Köln: Könemann, 1999.

BOLTON, B. A new general catalogue of the ants of the world. Cambridge, MA: Harvard University Press, 1995.

BORGMEIER, T. Revision der Gattung Atta Fabricius (Hymenoptera, Formicidae). Studia Entomologica, Petrópolis, v. 2, n. 1-4, p. 321-390, 1959.

BROWNE, M. Practical Taxidermy: A manual of instruction to the amateur in collecting, preserving, and setting up natural history specimens of all kinds. To which is added a chapter upon the pictorial arrangement of museums. With additional instructions in modelling and artistic taxidermy. London: L. Upcott Gill, [ca. 1890].

BRUNO, E. da S. História e tradições da cidade de São Paulo. Rio de Janeiro: José Olympio, 1953.

BÜCHNER, L. La vie psychique des bêtes. Paris: C. Reinwald, 1881.

CAMARGO, O. B. de. Jules Martin, artista, patriota, empreendedor. São Paulo: Edicon, 1996.

CARDIM, F. Tratados da terra e gente do Brasil. Rio de Janeiro: J. Leite, 1925.

CASCUDO, L. da C. Dicionário do folclore brasileiro. Rio de Janeiro: Instituto Nacional do Livro, $1954 a$.

. Comendo formigas. Sul America, Rio de Janeiro, n. 135, p. 6-8, $1954 \mathrm{~b}$

CHINNERY, R. J. A Record of Spicers 1798-1960: history of a famous taxidermy firm Peter Spicer and Sons of Royal Leamington Spa. Leamington: Victorian Taxidermy Company, 2001.

COSTA, E. V. da. Alguns aspectos da influência francesa em São Paulo na segunda metade do século XIX. Revista de História, São Paulo, n. 142-143, p. 277-308, 2000.

COTRIM, M. B. Presepio de Embu não tem Reis Magos, mas é ornado com iça vestido de gente. Folha de São Paulo, São Paulo, 1 fev. 1962. Caderno 2, p. 8.

DELLA LUCIA, T. M. C. As formigas cortadeiras. Viçosa: Universidade Federal de Viçosa, 1993. 
EDMUNDO, L. Recordações do Rio antigo. Rio de Janeiro: Editora “A Noite”, 1950.

ELLIS, R. Monsters of the sea. New York: Alfred A. Knopf, 1996.

FIGUEIREDO FILHO, J. de F. O folclore no Cariri. Fortaleza: Imprensa Universitária do Ceará, 1962.

FOREL, A. A fauna das formigas do Brazil. Pará: Typographia de Alfredo Silva, 1895.

FRANÇA JÚNIOR, J. J. da. Teatro de França Júnior. Rio de Janeiro: MEC-SAC, 1980.

FREITAS, J.A. de Excursão pelos dominios da entomologia. Recife: Typographia Universal, 1886.

FROST, C. A bistory of British taxidermy. Long Melford, UK: The Author, 1987.

GOELDI, E. Observações e impressões durante a viagem costeira do Rio de Janeiro ao Pará. Boletim do Museu Paraense de Historia Natural e Ethnographia, Belém, v. 1, n. 1, p. 44-57, 1894.

GONÇALVES, C. R. Contribuição para o conhecimento do gênero Atta Fabr., das formigas saúvas. Boletim da Sociedade Brasileira de Agronomia, Rio de Janeiro, v. 5, n. 3, p. 333-358, 1942.

HASSIG, D. The mark of the beast: the Medieval bestiary in art, life, and literature. New York: Garland, 1999.

HENNING, M. Anthropomorphic taxidermy and the death of nature: the curious art of Hermann Ploucquet, Walter Potter, and Charles Waterton. Victorian Literature and Culture, Cambridge, v. 35, n. 2, p. 663-678, 2007.

HICKS, C. Animals in early medieval art. Edinburgh: Edinburgh University Press, 1993.

HÖLLDOBLER, B.; WILSON, E. O. The ants. Berlin: Springer, 1990.

JAY, R. Jay's journal of anomalies. New York: Quantuck Lane, 2003.

KLINGENDER, F. Animals in art and thought to the end of the Middle Ages. Cambridge, MA: MIT Press, 1971.

LEHANE, B. The compleat flea. London: John Murray, 1969.

LENKO, K.; PAPAVERO, N. Insetos no folclore. São Paulo: Conselho Estadual de Artes e Ciências Humanas, 1979.

LENKO, K.; PAPAVERO, N. Insetos no folclore. São Paulo: Plêiade, 1996.

LEY, W. The lungfish, the dodo, and the unicorn. New York: Viking, 1941.

MAETERLINCK, M. A vida das formigas. Lisboa: Classica, 1937.

MAGALHÃES, C. de. Viagem ao Araguaia. São Paulo: Nacional, 1946.

MARICONI, F. A. M. As saúvas. São Paulo: Ceres, 1970. 
MENDES, A. de C. Figuras antigas. São Paulo: O Estado de S. Paulo, 1927.

MOURA, P. C. de. São Paulo de outr'ora, evocações da metropole. São Paulo: Melhoramentos, 1932.

NÉTO, I. L'animal miroir de l’homme: petit bestiaire du XVIIIe siècle. Paris: Musée Cognacq-Jay, 1996.

OLIVEIRA, M. L. F. de. O registro dos limites da cidade; imagens da Várzea do Carmo no século XIX. Anais do Museu Paulista, São Paulo, v. 6-7, n. 7, p. 37-60, 2003.

OTTINGER, D. Chimères. Monaco: Actes Sud, 2003.

PLOUCQUET, H. The comical creatures from Wurtemberg. London: T. Nelson, 1861.

RANSOME, H. M. The sacred bee in ancient times and folklore. London: George Allen \& Unwin, 1937.

RESL, B. (Ed.). A Cultural History of Animals in the Medieval Age. Oxford: Berg, 2007.

SAINT-HILAIRE, A. de. Segunda viagem ao interior do Brasil, Espirito Santo. São Paulo: Companhia Editora Nacional, 1936.

SALISBURY, J. E. The beast within: animals in the Middle Ages. New York: Routledge, 1994.

SMITH, P. H.; FINDLEN, P. Merchants $\&$ marvels: commerce, science, and art in early Modern Europe. New York: Routledge, 2002.

TARZIA, A. História do presépio. São Paulo: Paulinas, 1994.

TAUnAY, A. d'E. Historia seiscentista da Villa de São Paulo. São Paulo: Typographia Ideal, 1926-1929.

TESNIÈRE, M. H. Bestiaire médiéval: enluminures. Paris: Bibliothèque Nationale de France, 2005.

TOLEDO, B. L. de. Prestes Maia e as origens do urbanismo moderno em São Paulo. São Paulo: Empresa das Artes, 1996.

VULCANO, M. A.; PEREIRA, F. S.; MENDONÇA, N. T. de. Esboço monográfico: Hypocephalus armatus Desmarest, 1832 (Coleoptera, Hypocephalidae). Lundiana, Belo Horizonte, n. 1, p. 2348,1980 .

WHITLEY, G.P. Jenny Hanivers. Australian Museum Magazine, Sidney, v. 3, n. 7, p. 262-264, 1928.

ZUCKERMAN, S. The ape in myth \& art. London: Verdigris, 1998.

Artigo apresentado em 9/2008. Aprovado em 11 /2008.

Annals of Museu Paulista. v. 16. n.2. July - Dec. 2008. 